\title{
'The rats are still with us': Constructing Everyday Life at the Anacostia Museum in Washington, DC
}

\author{
Robyn Autry* Wesleyan University in CT
}

\begin{abstract}
How did the black cultural politics of the 1960s prompt the Smithsonian to break with tradition and establish the first experimental black community-based museum in Washington DC? Using a historical perspective, I examine how political-economic and institutional forces combine with more ideological concerns to construct flexible representations of race, urbanism, and community over time. I follow these developments across three decades to examine how internal and external factors shape the exhibition of group identity and collective pasts. Drawing on primary and secondary sources, including interviews with museum staff, newspaper articles, and Smithsonian archives, I illustrate how activist-minded staff at a local museum worked to construct an image of group identity and urban culture through curation, while negotiating symbolic, political, economic, and institutional pressures on cultural production.
\end{abstract}

Key words: community museums, racial identity, memory, urban, everyday life

\section{Introduction}

When former US president Andrew Jackson accepted a gift of over half a million dollars from John Smithson, an English scientist with royal ties, to create a national research and educational institution neither envisioned that over 100 years later it would host an exhibition about rat infestation in a low-income historically black neighbourhood. The Anacostia Museum opened in 1967 as an 'experimental facility' to bridge social divides between the austere National Mall and the city's most marginalized residents. Responding to requests from local youth and children asked to describe issues facing their community, museum staff decided to mount an exhibition about the "urban ecology of the Norway rat." On the surface it was a simple installation largely comprised of mounted pasteboards, but it broke new ground in the museum world, shattering the decorum of aristocratic Smithsonian. As the Anacostia Museum temporarily became home to caged live rats, staff members sought to animate the issues facing a poor community.

This approach reflected the will of a staff unburdened by the limits of traditional museology due to their longstanding investments in community organizing and social change. This representation of local culture brought to the fore a theme less unsavoury than might appear as it elevated the rat as symbol of social deprivation, conjuring up images from the opening scene of Richard Wright's Native Son when Bigger and Buddy face-off with a huge black rat in their one-room apartment. The Anacostia Museum, like Wright's novel, uses the visceral imagery of everyday life to construct broader narratives about the boundaries of the social in an unequal America. This case raises a number of questions about the social construction of the everyday in relation to national narratives about identity, belonging, and social change. I use a historical perspective to examine the uneven or fluctuating approaches to this project - bridging national and local iterations of identity - at one community-based museum with unique ties to the national vis-à-vis the Smithsonian.

How can we account for popularity of a Smithsonian museum exhibition organized around rats? Here, the ordinary, the banality of everyday life, is transformed through the 'magical' power of the past into objects of fascination that signal belonging and hope as much as social 
marginalization. Indeed, as Benedict Anderson (1991) observes, museums are institutions of power that reproduce ideas about nation by exhibiting specific styles of imagining the criteria for membership in the national community. In his brief discussion of museums as sites of nationbuilding, Anderson leaves unanswered questions about the relationship between sub-national communities, the national, culture, and memory. First of all, do these communities imagine themselves in the same fashion: as equal members in a sovereign territory characterized by horizontal membership? What role does public culture play in their imaginings of themselves? Who exactly produces these images and how are they then cast onto a larger population as representative? The growing popularity of community-based museums as an outgrowth of the civil rights activities of the 1960s speaks not only to the importance of museums but also to the importance of local, everyday experiences for members of racialized social groups.

As cultural theorist Stuart Hall (2001) contends, museum collections and practices are best understood as highly selective attempts to stabilize or fix narratives; they are limited by the nature of display as much as by the structure of narrative. What does it mean to endeavor to narrate and then stabilize a phenomenon as elusive and illusory as the everyday? The everyday, according to French sociologist Henri Lefebvre, is an inherently fragmented space characterized by the irreconcilable contradictions of contemporary social life (Lefebvre \& Levich: 1987:1-17). How do museum staff attempt to rein in and stabilize the frenetic energy and imagery of the everyday life to fit the confines of narrative and exhibitionary practice? They do so by selectively amplifying and in some cases inventing certain aspects of urban life and minimizing or recasting others. As Hall points out, all museums are engaged in this type of production, but the question lies in the extent to which this productive work is rendered visible in displays and programming.

Too often artificial distinctions are drawn between cultural and structural explanations of urban culture, obfuscating the way political, economic, ideological, and cultural phenomena interact. ${ }^{2}$ Place attachment and collective identity and memory are important cultural aspects of urban society, but they cannot be separated from the structuring influence of political and economic realities or contexts. Some sociologists examining cultural change and expression in urban societies have illuminated the constitutive nature of the political economy and the culture of cities. For example, Sharon Zukin (1995) developed a series of case studies about the tension of urban life through the lens of popular public culture, which is increasingly shaped by the interests of private capital and industry. In adopting an historical perspective on communities and museums, the following analysis explores how a series of social conflicts and changing political-economic forces shaped urban cultural expression and institutional development.

I specifically focus on the emergence of a black community museum in the late 1960 s to underscore the confluence of black community mobilization, cultural expression and production, and institutional change. On the one hand, exhibitions at the Anacostia Community Museum render visible what was glossed over or ignored in national narratives as staff and community members privilege their own perspectives and experiences as display-worthy. Yet, I also consider how these local re-workings are constructed and deeply shaped by the work of a select group of community leaders and museum staff despite the grassroots appearance or packaging of museum content. Further, while the museum breaks with national narratives by focusing on the local experiences of marginalized communities, its relationship to post-civil rights ethno-racial ideologies is more complex and less confrontational than one might assume given its primary status as a 'black' museum.

This case situates the problems of community in segregated urban space - defining members, imagining boundaries, and consciousness-raising - among wider concerns about national race politics, urban culture and tourism, and institutional capacity-building and survival. Drawing on interviews with staff, tours, newspaper articles, and museum archives, I explore social forces that turned the logic and conventions of museums upside down without upsetting their social legitimizing power and function. In doing so, I highlight the role of political-economic and institutional imperatives in determining how representations of local experiences and identities are produced and displayed. I find that three factors were especially critical in shaping the appropriation of museums as vehicles for group-making and community mobilization: 1) the growth of the black museum movement and its impact on established museums that were particularly vulnerable to public pressures; 2) internal and external political-economic and 
institutional pressures on museum operation; and 3) socio-economic and demographic change in the neighbourhood over time. In contrast to theories of institutional convergence, ${ }^{3}$ these factors combine in unexpected ways over time, suggesting that institution-building is uneven and conflict-ridden as are the cultural products and consumption patterns associated with it.

\section{Revolutionizing the Smithsonian (1967 - 1980)}

Removed from the bustle of Washington's political core, Anacostia's history is firmly rooted in the development of Washington DC and its struggle for self-government. As the freed African and African American population in the region increased and whites left, it became a predominately black community. It is known for its deep involvement in abolitionist and antilynching campaigns, spearheaded by Fredrick Douglas, one of Anacostia's most prominent residents. This community-based mobilization continued well into the civil rights era as Anacostia became a hotbed of social discontent in the nation's capital over segregation in employment and housing markets. Like many other urban areas, working class and unemployed African Americans made up a large percentage of the population as African Americans with more resources began moving to the suburbs, starting in the 1970s. Earlier though, during the 1950s and 1960s, Anacostia was home to numerous community-based campaigns, in addition to less organized rioting, that cut across class lines.

This served as the backdrop for the decision to situate a Smithsonian museum in the heart of one of Washington's most socially and economically marginalized neighbourhoods. The museum emerged in the context of a shifting social climate and escalating protest against multiple forms of oppression and discrimination. Urban rioting and protest in Washington DC was concentrated in areas heavily populated by African Americans, such as Anacostia, located east of the Anacostia River in the district's southeast quadrant. In the midst of this, complaints were leveled against the Smithsonian for its lack of minority representation, particularly African American, in its collections and among its administrative and curatorial staff. As late as 1983, only $2 \%$ of top Smithsonian professional staff were black, while $76 \%$ of its guards, $55 \%$ of its craftsmen, and $36 \%$ of its clerical staff were black. ${ }^{4}$

R. P. Ripley, then Secretary of the Smithsonian, vowed to usher the institution toward greater inclusivity in its holdings and public image. He and other staff members set out on a campaign to create a storefront museum in a low-income minority neighbourhood in Washington, D.C. Far from being a reflection of general consensus among Smithsonian ranks however, Ripley and his associates were seen as mavericks, carving out a new path despite many who opposed the idea. They were committed to expanding the reach of the Smithsonian and its education mission extending its reach into one of the city's most isolated neighbourhoods. Secretary Ripley recognized the educational power of the nation's leading cultural institutions and understood that segregation and social inequalities were keeping many minorities away. He explained:

To a large extent, people from rundown neighborhoods tend to stay there. They tend not to be mobile, or to move much out of their district, except in the transient sense from slum to slum. Such people ... are likely never to go to a museum at all ... They may easily feel lost as they wend their way along an unfamiliar sidewalk toward a monumental marble palace. They may even feel hostile. If the above is true, then the only solution is to bring the museum to them. (Ripley quoted in James 2004: 39)

This rationale for establishing a storefront museum could be read as an iteration of what would come to be known as the 'culture of poverty' thesis in circulation at the time, whereby the reproduction of poverty is explained by the lower social class developing habits, attitudes, and values that preempt assimilation into the middle class. Of course, this argument has been widely critiqued as overlooking the structural causes of concentrated poverty and its perpetuation. ${ }^{5}$ Yet, cultural entrepreneurs like Ripley exhibited an almost missionary zeal to alleviate what they saw as the pathological effects of poverty.

Despite the problematic language and assumptions used to articulate their understanding of the cultural impoverishment of black urban residents, the idea was motivated by concerns 
over low minority attachment to and identification with national culture, made manifest in anemic attendance rates, so an official committee was formed to create a new 'experimental facility.' After canvassing several inner-city locations, they settled on Anacostia, attracted by its wealth of community organizations and its historic significance. Unsure how a museum would operate in such a location, the Smithsonian committee sought a museum director unlike any other at its network of museums. The job description called for someone with 'a demonstrated ability to organize and maintain community activities... and the ability to show or explain how things work is highly desirable.' (Quoted in Martin-Felton 1993: 20) ${ }^{6}$ John Kinard, a prominent community organizer, was courted and eventually convinced to serve as its first director -Kinard would go on to serve as the museum's director for over twenty years. During his tenure, staff and volunteers were guided by the original mission of the museum to serve as a public site for local residents to congregate and reflect on their lives, experiences, and cultures. Museum staff members were deeply involved in local politics and political campaigns on issues ranging from unemployment to affordable quality housing. They knew that:

There was little doubt in the minds of many closely associated with the museum that the decision to locate this experimental facility in Anacostia was directly related to the social, political, and racial climate of the 1960s in the country generally and in Anacostia in particular. (Felton 1993: 28)

From the outset, the museum was seen as a trailblazer, drawing out the participation and support of people routinely left out of representations of national culture and heritage. Of course, the concentration of this social experiment off the National Mall and outside the established museums like the National History Museum is telling. But this relative isolation also proved to be advantageous, as museum staff were able to reconfigure their mission and activities with only minimal oversight.

However, the visions of Smithsonian officials and museum staff proved incongruent. From its inception, there was no consensus on the overarching mission or focus of the new museum nor its relationship to the neighbourhood activist networks many of its early staff and volunteers were deeply embedded in. Smithsonian officials insisted that the new museum operate as a conduit for the museums on the Mall, to broaden the audience base of these national museums. Kinard and other community members, however, saw the museum as an opportunity to address local concerns and build a sense of community. Kinard never accepted the idea that the purpose of the museum was to bolster African American attendance at the museums on the Mall. In fact, he questioned the relevance of these museums for African Americans stating, 'People are not going to insult themselves by going to a place that does not respect them. Where they don't see themselves, they don't visit.' ${ }^{7} \mathrm{He}$ and his colleagues sought to redesign the museum as one that recast national narratives from the perspective of black history and contemporary experience. Kinard argued, 'It does us no good to show ourselves in isolation the way whites have shown themselves in isolation from us. ${ }^{8}$ The goal, rather, was to use the museum to insert black experience into the national story, creating a more inclusive portrait of American culture and history than one might otherwise encounter at any mainstream museum at the time let alone the Smithsonian. Taken further, Kinard came to see museum curators as important social actors who were 'responsible for the preservation of the soul of man.' ${ }^{9}$ This almost existential mission was operationalized through the positioning of the museum into a space to uplift and empower blacks.

I have a fear more sociological than anything, a fright induced by circumstances, ones that don't allow people full growth. Because circumstances determine so much, and an inner-city kid might have the paranoia that not only does the larger world not belong to you, but you don't belong to you. Not to have a sense of identity is a fear. ${ }^{10}$

It should be said that this articulation of the museum's work is not altogether different from the missionary stance taken by Ripley and others. While Kinard was a member of the neighbourhood and saw himself as speaking on behalf of those he personally identified with, he was deeply invested in the idea that a museum - maybe one unlike that imagined by Ripley - would insert a positive uplifting element in the neighbourhood that could steer youth in the 'right' direction. 
Indeed, Kinard and his colleagues seized on the museum form as a platform to encourage blacks to situate themselves historically, to see themselves as historical subjects with agency to direct their future trajectories. In this sense, community leaders like Kinard saw the potential of museums to support their activist investments in reimagining the relationship between heroic narratives of the nation and historically marginalized groups. Yet, these were their goals, not those of the people they sought to reach, rendering the project fundamentally paternalistic, regardless of whether we sympathize or identify with the mission.

To fully appropriate the museum as a cultural site sensitive to the experiences and stories of people historically marginalized from mainstream institutions, Kinard wanted local residents to feel a sense of ownership and personal investment in the project he and others established on their behalf. This spirit was present from the beginning as volunteers, including local youth, worked to renovate the Carver Theater, an abandoned site selected as the new museum's home. Clearly, the efforts that went into the creation of this museum parallel other community-based mobilizations to encourage specific forms of consciousness-raising and black empowerment.

\section{The Everyday and Identity}

Before the staff committed themselves to levering the everyday as a site of identity claim-making, they shed the founding vision of the museum. Shortly after the museum opened, they generated a space to reconceptualize museums as vehicles to complement their broader community-building efforts; in this case, one that existed outside the watchful eye of the Smithsonian leadership. The opening exhibition was the first and only one to explicitly reflect the founding mission of Smithsonian officials, showcasing a variety of odds and ends borrowed from museums on the Mall. Officials had never intended for the Anacostia Museum to design and develop its own exhibitions and programmes, so they were unprepared for the changes orchestrated by Kinard and others determined to re-invent the museum to serve local interests. They were able to achieve this by securing outside funding from the Carnegie Corporation, the Ann S. Richardson Fund, the Meyer Fund, the Irwin-Sweeney-Miller Foundation, and 'neighbourhood residents who contributed some sums as small as 25 or 50 cents' (Martin-Felton 1993:20).

The determination to create a museum with local resonance - in contrast to those celebrating heroic narratives of nation on the Mall - led to a series of unconventional exhibitions that marked a decisive break with the 'storefront' vision of the museum. In addition to the reconceptualization of appropriate museum content, staff and board members re-created how museum activities were performed, drawing in members of the community and working in close collaboration with local organizations and volunteers to co-create exhibition materials and community programmes. Two exhibitions epitomize this period: 'The Rat: Man's Invited Affliction' in 1969 and 'Lorton Reformatory: Beyond Time' one year later. The 'rat' exhibition drew wide attention for its daring content and display style, especially in relation to other Smithsonian museums. The show included live rats in cages and panels about the urban ecology and history of the rat.

The focal point of the exhibit was a simulated rat environment: a backyard with live rats. Visitors could see how rats exist and survive as well as their destructiveness and disease-carrying potential. ${ }^{11}$

We have been most successful at being attentive to the needs of the people of Anacostia. Our problems are housing, education, transportation, health and sanitation. How does this notion of serving people jive with the museum structure? The 'Rats' gave us an awareness of the problem. The rats are still with us. ${ }^{12}$

The exhibition paved a way for the positioning of the museum as generative space within which the past, present, and future were strategically linked as a form of social commentary. Within this visual and textual language of identity, the viscerality of the everyday is afforded primacy as evidence of both social inequalities and black perseverance. Indeed, the 'rats' exhibition reflected frustrations with rat infestation in the neighbourhood and prompted an investigation into the problem in Anacostia and other inner city neighbourhoods by the local public health 
officials. ${ }^{13}$ Assistant Secretary for Public Service for the Smithsonian, William Warner, recognized these types of exhibitions as part of the museum's role as 'a "neutral corner" where community problems can best be ventilated and then later translated into action by others. ${ }^{14}$

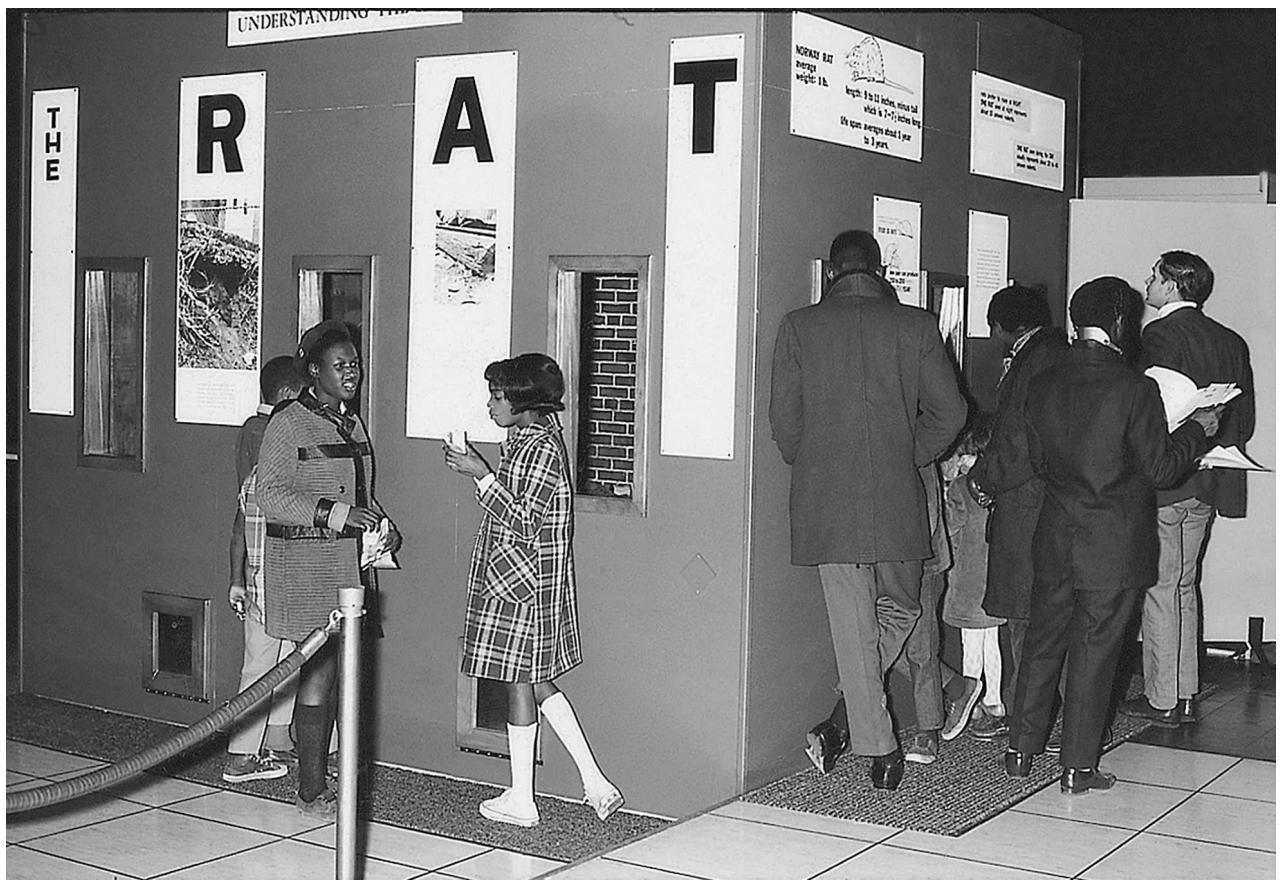

The Rat: Man's Invited Affliction, 11/16/69; Author unknown

The troubling spike in incarceration also served as a motivating force for an early exhibition about, and in collaboration with, the local prison: the Lorton Reformatory. This exhibition was even more unorthodox because it was shaped by the prisoners themselves, piecing together what their everyday lives were like behind bars through personal artwork and crafts, as well as a slide show featuring the inmates in musical and theatrical performances. ${ }^{15}$ Reflecting their activist impulses, museum staff hoped that the exhibit would be one that 'stimulated ideas of ways to help the inmates as well as legislation. ${ }^{16}$ John Kinard described it as a public service, a vehicle for greater 'understanding and appreciation of how men at Lorton 'spend the time' during their imposed sentences. ${ }^{.17} \mathrm{He}$ went on to state that:

This display of art work and of various crafts, the presentation of musical and dramatic programs, all attest to the creative spirit of these men whose talents are expressed here and who speak to us through this exhibit.

The Lorton exhibition was ongoing and included art displays, musical and theatrical performances, community workshops about topics ranging from drug abuse to religious expression in prison, and prison tours. The exhibition broke new ground as it decisively located those at the most extreme margins of society within the everyday of the neighbourhood; it effectively enveloped those easily stigmatized as socially undesirable or threatening as redeeming. This redrawing the boundaries of community to include those incarcerated within it underscored more than deep-seated frustrations with overrepresentation of blacks in the criminal justice system. It also reflected Kinard's mission to subvert popular interpretations of black culture and identity as pathological, and especially to ward off the internationalization of these sentiments by black youth, by emphasizing the shared humanity of all people.

These two exhibitions, as well as others about prominentAnacostia residents like Frederick Douglass and Anna J. Cooper, did more than challenge conventional museological practices. 
The focus of these shows was on public engagement and deconstructing the everyday lives of local residents, rather than more traditional museological concerns about the acquisition, collection, and display of material objects. The staff and volunteers had quieted suspicions that a museum would be an alien presence in Anacostia. Kinard stated:

\begin{abstract}
While there was great joy and the anticipation of better things to come for Anacostia when the Museum opened, there was also fear and uncertainty on the part of many. It was felt that a museum was just not the kind of institution the neighborhood needed, that it would prove to be not only irrelevant to the issues of concern to the community but totally alien, and judging from what was known about other museums, it might be so highbrow as to be an embarrassment or downright insult. ${ }^{18}$
\end{abstract}

The Anacostia Museum is neither a missionary project nor an idealistic effort to eradicate poverty, but a serious attempt to create a museum that reflects the achievements and failures; the aspirations and hopes of a people who are defined by geography. ${ }^{19}$

Kinard's history in community organizing provides the backdrop for his positioning of the museum as a consciousness-raising site that articulated a shared identity for a community facing similar social issues. This top-down group-making project treats cultural production and exhibition as an activist tool to advance social aims; all museums function according to some preconceived notion of the social that guides their mission and programming. While the Anacostia Museum made this social work more explicit, it still worked to mask the inherent paternalism undergirding its work as a representational project.

Yet, although Kinard's vision permeated the museum, new mechanisms for community accountability and responsiveness were attempted to create a more democratic climate. There were two advisory boards that approved and made suggestions for exhibitions: the Neighborhood Advisory Committee and the Youth Advisory Council. These committees operated as mechanisms to ensure that the museum's content was a reflection of the community and nurture a sense of ownership over an important social institution. With over 100 members representing various perspectives and visions for the museum, consensus-building and collaboration were arduous tasks that over time gave way as the size of the board shrunk and professionalization increased.

Unlike other Smithsonian museums catering to a broad national audience, the bulk of early visitors to the Anacostia Museum were local residents, especially schoolchildren. A shared identity, or rather identification, was pursued through the collaborative production and consumption of exhibitions conceived of by the community. As curator Portia James notes, this was certainly an 'inversion of the Smithsonian mission.' More broadly, it was an appropriation of an institution of power to serve the interests of historically marginalized individuals. Yet, the fiscal and professional realities of operating a museum set in a poor urban neighbourhood would constrain the museum's autonomy and ability to deepen public engagement and collaboration.

\title{
Institutional Dilemmas (1982 - 1990)
}

While the Anacostia museum and several other black museums grew out of the social protest activity of the 1960s, the realities of operating an institution dependent on outside funding and regular patronage would quell the revolutionary character of the museum. In that respect the case of Anacostia has a bearing on the organizational character of museums. Thus, for example, Paul DiMaggio and Walter Powell (1983) have identified 'institutional isomorphism' as an aspect of organizational change. They mean that organizations operating within any field tend to become more and more similar through shared professional standards and credentials required to compete for scarce resources, organizational contact, and the standardization of procedures and credentials. However, this case suggests that such isomorphic or homogenizing tendencies are neither inevitable nor uniform; in fact, this drift toward homogeny can even be reversed to assert and maintain a distinctive niche. 
During the early 1980s the Anacostia neighbourhood experienced a series of blows that would propel the museum in new directions. Political neglect, increasingly black suburbanization, and high unemployment rates began to take their toll on Anacostia as homelessness and crime rates rose. Located in the historic Carver Theater in the center of the neighbourhood, the museum had reaped the symbolic and material gains of its location, but as the area declined so too did attendance, and staff began to scout alternative venues. Of central concern was a nearby area known as 'the corner' that was originally a lively public space that deteriorated and became notorious for illicit activities and as the hang out spot for drug addicts and alcoholics. The museum staff started to receive complaints about having to walk pass 'the corner' to get to the museum. Kinard revealed:

Those people created problems for some visitors, who saw them and drove right past, but in 20 years never did anybody bother anybody coming to the museum. The only injury was done to themselves. ${ }^{20}$

Even though Kinard was among those clamoring for a new home, we can still detect the almost spiritual qualities motivating his involvement in cultural activism as a means to access shared humanity. Yet, this also reflects an unwillingness or inability to incorporate, let alone celebrate, aspects of the everyday that underlined the institutional viability of the museum.

While the original location was in a bustling area of the neighbourhood, it was never without its challenges. Long-time programme coordinator, Zora Martin-Felton also recalled that because Kinard and others were well-regarded community leaders, the building and staff had always been treated with respect. Since its opening, she insisted the museum occupied a special place in the community - as rare hopeful and positive reflection of itself. She noted:

People on the corner, children who came everyday - they all had so much respect for him and the museum. How else would you explain that with all the things going on here, the museum has never been vandalized and we've never found graffiti on the walls? ${ }^{21}$

Yet as the neighbourhood changed so to did the perceived everyday threat of its location. While the placement of the museum in an impoverished and minority neighbourhood was the original intention, this made the museum vulnerable to the many the problems plaguing the area, including unemployment and crime. These conditions certainly affected the museum's ability to attract and maintain support. Kinard pressed the Smithsonian for a new site, despite the accessibility and high visibility at its current home. In 1981 he wrote to the Smithsonian's Planning Committee:

The Anacostia Museum's public space ... [is] currently housed in rather decrepit leased spaces on one of the most crime riddled intersections in the city. ... Drugs and violence in the immediate vicinity make entrance to, and ergo from, the museum physically dangerous. Dangerous to visitors and staff alike. Certainly, not a pleasant addendum to the visitors' overall "Smithsonian Experience". ${ }^{22}$

Here, Kinard deliberately invokes the Smithsonian, rather distancing himself and the museum from it, to bolster his appeal to relocate the museum to another part of the neighbourhood. He and others had their eye on vacant space in Fort Stanton Park, a former military installation overseen by the National Parks Service.

This strategic institutional re-identification with the Smithsonian was not limited to requests for relocation. Kinard also stressed that the museum wanted to expand its collection, staff, and departments, which would require additional space than was available at the Carver Theater. This period, the early to mid-1980s, marks a shift in the museum, as Kinard and others grew determined to prove that it was as professional and legitimate as the other Smithsonian museums. The alternative museological approach and diverse backgrounds and training would eventually fuel an identity crisis at the Anacostia Museum, as staff members sought equal status and support with other Smithsonian museums. Criticisms from within and beyond the 
Smithsonian served as the backdrop of these changes. In 1980 the Smithsonian released a highly critical evaluation of the museum produced by a five-member committee.

By that standard [of the nation's best publicly funded museums] the Anacostia Neighborhood Museum is disappointing. While there was no attempt to probe for the basic causes of the situation, there is little doubt that intellectual and professional isolation is one of the [museum's] major problems. It is perhaps most strikingly apparent in the areas for which the Smithsonian has earned a welldeserved internal reputation - research, conservation, and curatorial expertise. ${ }^{23}$

These criticisms came as Kinard and others were pressing the Smithsonian for a new facility and more resources to expand the museum's collections and programmes. Kinard responded strongly, dismissing the report as 'elitist' and unreasonable considering the small size and unique mission of the museum. 'How can you compare us to Smithsonian museums that have been around for more than 100 years? We have learned from our mistakes and we are now much more professional. ${ }^{24}$ By accepting the ideology of professionalism as a measure of credibility, museum staff inadvertently undermined the museum's ability to reinvent itself as an altogether different sort of representational project with local resonances.

Ironically, the very isolation and experimental status that afforded the staff autonomy to reconfigure the museum form also constrained its ability to evolve over time. Members of the old guard at the Smithsonian were uncomfortable with the content of some of the museum's exhibitions and questioned whether the museum was overstepping its original mandate. Others criticized the style and quality of the exhibits, arguing that they were amateurish and did not live up to Smithsonian standards, noting that many of the staff members at the museum did not hold advanced degrees. While earlier exhibitions pushed the envelope by opening the museum to new topics, audiences, and museological techniques, the exhibitions themselves were simple: mostly pasteboards with typed text. There were few artifacts and the museum was originally prevented from acquiring a permanent collection, reflecting the thinking among top Smithsonian officials that the Anacostia Museum was a special type of facility. In pursuing the acceptance and recognition of the museum as on par with other Smithsonian attractions, the museum underwent a professionalization of its staff and reduced the size and representation of its advisory board.

Kinard and his staff took issue with the idea that their museum did not and could not live up to the high standards and quality of the museums on the Mall due to the museum's focus and lack of advanced training of its staff. While Kinard had a bachelor's degree in sociology and history, his background in community organizing along with that of his staff, and their embeddedness in the community, are what made the museum unique. Yet, charges that the museum was reaching beyond its capacities in its desire to create a permanent exhibition and develop more sophisticated installations fueled the professionalization of its staff during the mid to late 1970s. This period of intense professionalization led to the creation of specialized departments, the expansion of paid staff, more emphasis on expert credentials, and diminished efforts to cultivate public engagement and participation, although the museum did organize a training academy for individuals without formal training to learn curatorial strategies, installation development, and exhibition design. ${ }^{25}$ It was during this period that the museum dropped 'neighborhood' from its title and institutional identity.

By the time the museum opened at its new location at Fort Stanton Park in 1987, its name officially changed from the Anacostia Neighborhood Museum to the Anacostia Museum. A few years later the name changed to the Anacostia Museum and Center for African American History and Culture. These changes were accompanied by a shift in focus from the Anacostia community to African American history, art, and culture more generally. Curator Portia James remarked that the shifting content concentrations "have not been serially adopted, but integrated each within the other - even as internal and external social changes posed different challenges. ${ }^{26}$ As James argues, the identity and image of the Anacostia Museum shifts like any other institution. The more interesting question is how and why these shifts occurred and in what context. This ideological shift coincided with the physical shift or relocation to Fort Stanton, where the museum rests atop a hill removed from the heart of the neighbourhood and overlooking the rest of the city. 
The staff were repositioning the museum from its local orientation to a national orientation vis-à-vis the Smithsonian museums on the Mall. Kinard insisted that this shift was needed to correct the distortions and deletions of African Americans in traditional historical accounts at museums and more generally in society. The boundaries of the museum's imagined community were no longer confined to its geographical location, as race became a more central criterion than place. The shift was also a reflection of the growing chorus for a national African American museum on the Mall during the mid to late 1980s. While Kinard was initially opposed to the national museum, fearing the effect it would have on the deep network of black museums across the country, especially his own, he quickly came to support the effort. By the time of his death in 1989, Kinard was one of the strongest supporters of the museum, welcoming it as a complement to the work being done at the Anacostia Museum.

Ironically, plans for a new national museum would indeed endanger the museum's survival as Smithsonian executives and politicians began to raise questions about the redundancy of funding two black museums, especially given the declining attendance at the one located five miles away from the Mall. Indeed, as the museum became more removed from its surrounding neighbourhood and residents, it grew increasingly reliant on and eager to attract tourists visiting the Mall. This changing political-economic, institutional, ideological, and geographic landscapes set the stage for ongoing reformulations of the social definitions of community to align these multiple and sometimes contradictory realities.

Defining Community in a Changing Context (1990 - present)

The problem of defining the boundaries of community is as central theme of all groupmaking projects, but one that is inherently fraught with contradictions, especially in gentrifying cities with high levels of immigration. Adding to this challenge, legislation to build a national African American museum - the National Museum of African American History and Culture Act of 2003 - would compel the Anacostia Museum to once again reconsider and reevaluate taken for granted definitions of community, race, and ethnicity as a matter of institutional survival. Following Kinard's passing in 1989, the 1990s represented a time of ideological expansion at the museum, when the most serious efforts were taken to reposition it as an African American history museum with a comprehensive scope. Just as it had broadened its conception of community outside the geographic limits of neighbourhood, focusing more expansively on black identity threatened to render the museum redundant.

Most discussions about the struggle over creating a national African American museum focus on the political maneuvering to block and advance various legislative attempts. ${ }^{27}$ Yet, there was only mild support at best for the museum within the Smithsonian administration itself, which did not show any enthusiasm for the various proposals to establish a new museum. Then director of the Smithsonian, Secretary I. Michael Heyman, was vague about his support for the legislation to create an African American museum on the Mall.

My own view deep down is that what the Smithsonian really can do is try to underscore the commonality of people. Whether or not that justifies separate museums for separate ethnicities is a real question. I really don't have to face up to that at the moment, because it is pretty clear we are not going to get funding for separate museums. ${ }^{28}$

Of course, the campaign to create the museum, itself a continuation of the agitation that led to the creation of the Anacostia Museum in the 1960s, originated from dissatisfaction with the Smithsonian's track record and current representations of national identity, or rather the nature of community defined by national membership. Despite the ambivalence and virtual silence from the Smithsonian in the public debate, legislation to establish the national museum finally passed the Senate in 2004.

While Kinard had always believed a national museum could complement the work of the Anacostia Museum, it was far from clear how this would work. Part of the problem was that the museum had moved away from its early local orientation toward a more general black identity narrative to gain legitimacy as much as attract a more national audience - or at least those visiting the museums on the National Mall - beginning in the mid-1980s. Increased competition for funds, artifacts, and audiences with the new museum located on the Mall threatened the museum's survival and autonomy. The future African American national museum posed a serious 
threat to the continued existence and federal support of the Anacostia Museum, necessitating yet another reorientation; this time a return to more local stories about black experiences in the community, but waves of immigration and the first signs of gentrification complicated these efforts along with the less active (or activist) role of the museum in the neighbourhood.

The need to restructure the museum in lieu of these external shifts was intensified by Kinard's untimely death in 1989. The interim director Steve Newsome was instrumental in staging a reminder of community museums' distinctive approaches to national history by focusing on Anacostia's changing demographic profile as a microcosm of changes occurring across black communities in the United States. The 'Black Mosaics' exhibition examined the lives and experiences of black immigrants in Anacostia, whose stories challenged conventional perceptions of a homogeneous black identity. ${ }^{29}$ Recognizing that tourists would be even less likely to make the trek from the National Mall to southeast Washington D.C., the exhibition was the first evidence of the museum's shift back toward its original neighbourhood model. 'Black Mosaics' captured the co-creative spirit of some of the museum's earliest exhibitions as the focus was on the surrounding neighbourhood and residents were drawn in to participate in the creation of the displays. Children and youth interviewed older residents about their experiences, and staff and volunteers collected family photographs and heirlooms to create a portrait of Anacostia's black immigrant population.

Newsome and his colleagues had difficulty returning to the community-based model or re-creating the top-down approach to mobilizing support from the base for their representational work. Namely, the institutional reorganization of the museum during the 1980s had exacerbated the distance between the museum and the local residents. Museum staff found themselves working with people who had never been to a museum, were suspicious of its Smithsonian affiliation, and were reluctant to part with family photos and other heirlooms. While some community members boycotted the exhibit, asking what it had to do with African American life, its 1994 opening was highly regarded in the museum field and attracted new audiences. The exhibition raised important questions and exposed old assumptions about the homogeneity of the black experience in the United States, suggesting yet another re-imagining of African American community within a local context.

In 2005 Camille Akeju was hired to resolve institutional tensions and revive the museum's mission, a task complicated by socio-economic and demographic changes in the local community. Once again, the name of the museum changed, this time to the Anacostia Community Museum. The change is meant to do more than distinguish the museum from the future national AfricanAmerican Museum. Akeju stresses that there is a need to reconsider what community means, especially given the demographic shifts occurring across American cities.

My sense of community is much more broad than was articulated by the Anacostia Museum in the past. There's no reason community has to be defined by race or ethnicity. These are not black issues and in order to sustain ourselves, we have to think of ourselves in a universal context. ${ }^{30}$

This is the third imagining of community at the museum: from the geographically bounded black neighbourhood, to all African Americans, and now to everyone's lived experiences in cities. This particular image of community and social belonging rests on conflation of race and ethnicity, an avoidance of the types of tensions revealed during the Black Mosaics exhibition.

This more abstract, universal understanding of community can potentially encourage visitors to see themselves in a broader context and encourage dialogue and understanding across groups, but it also presents challenges for a museum whose public image remains that of a black museum. The neighbourhood surrounding the museum remains overwhelmingly black, and the museum is still two trains and a bus ride away from the Mall. In addition, the staff members are trained in black history and culture and Akeju admits that there has been some hesitancy and even resistance from staff members who are committed to presenting information about blacks that is sidelined or ignored in conventional museums and mainstream media. ${ }^{31}$ Head curator, Portia James, expressed the difficulty of this task:

I'm actually intrigued by the idea of losing the ethnic specificity, to lose that focus. I mean, it's hard to say because that's all of our history, that's all of our work, and that's all of our expertise. 
But when I think of a museum of the $21^{\text {st }}$ century and I look at the changing demographics of American cities, I can just think there would be a lot of interest in challenging some of those boundaries, instead of saying 'This is my box and I'm staying in it.' Just look at what's going on around you in the cities - it's incredible ... it would be interesting to try to interpret some of that and share that discussion with the public. ${ }^{32}$

Indeed, what has been transpiring in Anacostia in the last ten years is remarkable. The area has seen an influx of black middle class residents and now young white professionals are beginning to trickle in too, drawn to the area for its close proximity to Capitol Hill and its lower housing costs. This demographic shift has brought with it rising suspicious and fears of displacement among long-time residents who welcome development but fear that it will come at their expense. For example, the owner of Anacostia River Realty, Darrin Davis, reported long-time residents opposed and even vandalized some of his firms' properties, which tend to attract young professionals. ${ }^{33}$ In fact, DC is among the fastest gentrifying metropolitan areas in the country, although most of this activity has been concentrated in neighbourhoods west of the Anacostia River, leaving Anacostia and other neighbourhoods east of the river relatively unaffected until most recently. ${ }^{34}$

The Museum's 40 th anniversary exhibition 'East of the River: Continuity and Change' represents these themes nicely. It shows how the staff are trying to reconstruct the everyday as a site of identity-making by placing local black experience within a broader context by exploring all communities east of the Anacostia River 'from a provocative yet universal perspective --- the struggle over land: who owns it, who controls it, who profits from it and how residents determine their own destiny'. ${ }^{35}$ Akeju hoped the exhibition would trigger discussions about current changes in Anacostia, about the demographic changes, as well as recent high-end residential and commercial developments along the river. ${ }^{36}$ Attention to these local issues and the desire to use the museum as a public platform harkens back to the early days of the museum under Kinard's leadership.

Just as visions of what urban life should be in the nation's capital shaped early efforts to build a museum in Anacostia, current plans to re-develop the area complicate efforts to imagine and police the boundaries of community. The Anacostia Waterfront Initiative promises to transform over forty acres of riverfront property for residential, recreational and commercial purposes, promising to attract new residents and visitors to this historically black and low-income neighbourhood. Unsurprisingly, this joint public-private urban renewal push has provoked conflicting feelings among local business owners and residents who appreciate the injection of resources into their neighbourhood, but fear that gentrification will eventually push them out of their homes.

Cultural production too is at the heart of debates about how the neighbourhood is changing and the nature of redevelopment. The museum must share a cultural space with the types of cafes, galleries, and shops that accompany urban redevelopment and gentrifying trends in urban areas. How will the museum compete for the attention and patronage of the new upwardly mobile residents without alienating long-time residents? Here again, we can detect remnants of the 'culture of poverty' mentality undergirding the first deliberations about the creation of the Anacostia Museum and then Kinard's later reformulation. The wave of gentrification in the area brought with it the Honfleur Gallery, an upscale art gallery that opened in 2007. Gallery owner Duane Gautier described it as 'something that could be in Soho or Paris.' ${ }^{37}$ At the time of its opening established residents questioned the relevance of the gallery and treated it as an alien space, while commentators urged that art would be the saviour of the blighted neighbourhood, a catalyst to alter public perceptions of it and attract private investment. Residents fear that like other formerly neglected districts, Anacostia will find itself 'colonized by art galleries'. Where does this leave the Anacostia Museum? Never a posh gallery, it has lost much of its local identification and affiliation, but it also lacks the high-end content to compete with galleries like Gautier's. The realities of gentrification - its promises, dangers, and ambivalences - create confounding puzzles for a staff already besieged with ideological and organizational tensions. 


\section{Conclusion}

The museum, like its surrounding neighbourhood, remains marginalized from the political and economic life of DC, despite the first tentative steps toward full-scale gentrification and reincorporation. Today, tourists visiting other Smithsonian museums on the National Mall have to take two trains and a bus to reach the Anacostia Museum. The politics of race, space, and representation converge in the evolution of a museum that is simultaneously funded by the national government, but that is also intellectually distinct and physically isolated from the panoply of Smithsonian museums on the Mall. The everyday realities of race and class manifest in the spatial politics of cultural production as producers ask themselves exactly who is their target consumer or audience.

The appeal of the everyday as a site of identity and group-making and a source of community mobilization is clear, but it begs questions about the nature of its construction. The emergence of black community-based museums was an outgrowth of the civil rights activities of the 1960s, privileging the local experiences of members of racialized social groups over dominant narratives of nationhood and national culture. Effectively, by appropriating an elite cultural form, the Anacostia Museum served as a public space and an institutional infrastructure that allowed early museum staff to augment their community-building work by fixing certain narratives of place-based group identity. The museum served to challenge dominant narratives of national history and culture by placing African American lives and experiences at the core of the national story, rather than at the margins. While this approach recognized and privileged a select set of narratives about historically marginalized voices and experiences, it did not avoid cultural biases and inaccuracies. In fact, the museum struggled with representing the fluid boundaries of community that crossed multiple racial, ethnic, geographic, and socioeconomic lines.

To some extent, as community members are more deeply involved in museum operations and the development of museum content, both the content and form of representations can shift, although the underlying distance between the represented and the representative is maintained. These observations support other research on the effect of social marginalization and exclusion from national culture on minorities' cultural expression and mobilization. ${ }^{38}$ In addition to cultural and ideological realignment, museums and museum development also raises questions about organizational capacities and sustainability. The political economy of these new forms of cultural expression and representation shed light on the relative autonomy and circumscribed control marginalized communities possess over time.

A series of political-economic, institutional and ideological factors influence the trajectory of change at the Anacostia Museum. Of particular importance were the museum's relationship to the black museum movement, its paradoxical relationship to the state vis-à-vis the Smithsonian, the institutionalization and professionalization of black cultural expression, and the haziness of racial and ethnic criteria in defining community in evolving cities. During the early years of the Anacostia Museum, exhibition ideas and content development originated within the surrounding community and reflected the concerns and interests of its members. The first exhibitions were installed at a fertile stage in museum's development and involved intense interaction with community members about the realities of their everyday existence. Conforming to Andrew Abbott's observations about the culture of professionalism, ${ }^{39}$ the professionalization of memory work at the Anacostia Museum became a vehicle for legitimation among more conventional museums in general, and in relation to the Smithsonian apparatus specifically, deeply influencing its internal logic and representational approach.

The evolution of the Anacostia Museum offers a view into broader discussions about the relationship between race, ethnicity, nation, and culture as constitutive elements of collective identity. It illustrates the persistence of race/ethnicity as key features of local and national identity and as factors that shape our sense of place. Museum staff continue to contend with what it means to be a community museum in a region dominated by a single racial group with deep cleavages along cultural, national, and class lines and in the context of gentrification - does that necessarily make it an African American museum? Yet, the new museum on the National Mall and the beginning stages of urban redevelopment echo the broader dislodging of assumptions about racial/ethnic, economic, and geographic homogeneity as the basis of 
community in modern cities. At its core, the historical trajectories at the Museum indicate the unevenness, internal contradictions, ideological interests, and professional ambitious that lurk in the background of representational projects, even those conceived of as correctives to longstanding and systematic misrecognitions, silences, and distortions in mainstream museums.

Received $27^{\text {th }}$ July 2014

Finally accepted February $12^{\text {th }} 2015$

\section{Acknowledgements}

I am grateful to the anonymous reviewers at Museum \& Society for their comments and suggestions. Thanks also to the staff at the Anacostia Museum for speaking with me on numerous occasions and to colleagues at the University of Wisconsin-Madison for feedback on earlier drafts of this article, especially Gay Seidman, Mara Loveman, Paul Bjerk, and Angela Autry Gordon. This piece also benefitted from the research assistance of Grace Carroll.

\section{Notes}

1 The Rat: Man's Invited Affliction opened in November 1969 and was displayed January 1970.

2 For a discussion of these tensions see, Borer, M. (2006). See also the subsequent debate between Borer and Hebert J. Gans also published in City \& Community, 6 (2) June 2007.

3 See DiMaggio, P., \& Powell, W. (1983).

4 Statistics are provided by Will Douglas, Jr., director of the equal opportunity office at the Smithsonian and quoted in 'The Missing Minorities', Washington Post, 5/17/83.

5 For a discussion of these arguments and the critiques in circulation during the 1960 s, see Valentine, C. (1968).

6 Quoted in Martin-Felton, Z., \& Lowe, G. (1993). A different drummer: John Kinard and the Anacostia Museum, 1967-1989. Washington, D.C.: Smithsonian Press p. 20.

7 Kinard quoted in "The Missing Minorities: New Smithsonian Panel Seeks Variety of Visitors," Washington Post, 5/17/83.

8 Kinard quoted in "Anacostia Museum: A Mixture of City, National Culture," Washington Post, 9/22/82.

9 Kinard quoted in "Anacostia Honor's Memory of a Man with a Mission," Washington Post, 8/12/89.

10 Kinard quoted in "Anacostia Advocate: Kinard Shaping a Neighborhood Museum into a Cultural Staple," Washington Post, 9/16/77.

11 Carolyn Margolis quoted in "Exhibits," Anacostia Neighborhood Museum. Washington, D.C.: Smithsonian Institution, 1972, p. 20. Margolis was the primary research assistant for the museum when it first opened.

12 Anacostia Museum Director John Kinard quoted in "Kinard: Shaping a Neighborhood Museum into a Cultural Staple," Washington Post, 9/16/77.

13 For a brief description of the exhibition, see James (2005: 373-93).

14 Letter to John Kinard included in Anacostia Neighborhood Museum. Washington, D.C.: Smithsonian Institution, 1972. 
31 Ibid

See Carolyn Margolis (1972: 23)

Anonymous visitor feedback printed in Anacostia Neighborhood Museum. Washington, D.C.: Smithsonian Institution, 1972, p. 51.

Quote from the foreward of 'Lorton Reformatory: Beyond Time', Anacostia Community Museum archives.

Kinard, J. (1972).

Kinard, J. (1972).Emphasis added.

Kinard quoted in "Heritage Home: The New Anacostia Museum and its Quiet Pleasures," Washington Post, 5/16/87.

Martin-Felton quoted in 'Anacostia Honors Memory of a Man with a Mission', Washington Post. 6/12/89.

"Proposal to Committee to Study Future Plans for Programs and Space at the Anacostia Museum," 24 November 1981, p. 1, cited in Chapter 4 of Martin-Felton, Z., \& Lowe, G. (1993: 30).

Reported quoted in 'Anacostia Museum Seeks New Status from Smithsonian; Anacostia Museum at a Crossroads', Washington Post, 3/6/80.

Kinard quoted in 'Anacostia Museum Seeks New Status from Smithsonian; Anacostia Museum at a Crossroads', Washington Post, 3/6/80.

nterestingly, the Smithsonian refused to fund this training academy, but funds were secured from the Carnegie Foundation for three years.

Museum curator, Portia James. From James, P. (1996) Building a Community-based Identity at Anacostia Museum. Curator, 39 (1) 19-44..

See Ruffins, F. (1998).

Heyman quoted from an appearance on a radio talk show in "African American Museum is Stalled," Washington Post, 7/30/95.

The exhibition was favourably reviewed, but triggered controversies in Anacostia with some local residents resenting the focus on black immigrants. For a detailed discussion of the exhibition, see Ray, E. (1995). For a brief account, see James, P. (1996)

Camille Akeju, interview conducted 20 August, 2007.

Portia James, interview conducted 21 August, 2007.

See E. Wax. "Gentrification Covers Black and White Middle-Class Home Buyers in the District. Washington Post, 7/28/11.

See P. Stein. "Portland is the Only City Gentrifying Faster than DC," Washington Post, $2 / 15 / 15 /$.

Museum brochure, also available on-line at http://anacostia.si.edu/exhibits/exhibits.htm. Also see 'The Smithsonian's Anacostia Community Museum Opens the Exhibition "East of the River: Continuity and Change" in Commemoration of its 40th Anniversary," Smithsonian media release, 9/17/07. 
36 The concerns involve plans to establish a riverfront district and new sports stadium. See David Nakamura's “In Ward 8, Residents Voice Skepticism of Poplar Point Plan," Washington Post, 1/21/07. See also Swope, C. (2004). Reinventing the district. Planning, 4(1).

37 Quoted in S. Kaplan. "The Honfleur Gallery Hasn't 'Saved' Anacostia, But it Has Made a Home for Art There," Washington Post, 8/1/14/.

38 For example, see Lowe, L. (1996)

39 Abbott, A. (1998).

\section{References}

Abbott, A. D. (1988) The System of Professions: an Essay on the Division of Expert Labor, Chicago, IL: University of Chicago Press.

Anacostia Museum and Center for African American History and Culture (2005) The Black Washingtonians: The Anacostia Museum Illustrated Chronology, Hoboken, NJ: J. Wiley.

Anderson, B. (1991) Imagined Communities: Reflections on the Origins and Spread of Nationalism, New York, NY; London, UK: Verso Books.

Bennett, T. (1995) The Birth of the Museum: History, Theory, Politics, New York, NY; London, UK: Routledge.

Billig, M. (1995) Banal Nationalism, London, UK: Sage Publications.

Borer, M. (2006) 'The Location of Culture: The Urban Culturalist Perspective', City \& Community, 5 (2) 172-97.

DiMaggio, P., \& Powell, W. (1983) 'The Iron Cage Revisited: Institutional Isomorphism and Collective Rationality in Organizational Fields', American Sociological Review, 48 (2), 147-160.

DiMaggio, P. (1991) 'Constructing an Organizational Field as a Professional Project: U.S. art museums' In DiMaggio, P., \& Powell, W (Eds), New institutionalism in organizational analysis, 63-82, Chicago, IL; London, UK: University of Chicago Press.

Eichstedt, J., \& Small, S. (2002) Representation of slavery: Race and Ideology in Southern Plantation Museums, Washington, D.C.; London, UK: Smithsonian Institution Press.

Foner, E. (2002) Who Owns History? Rethinking the Past in a Changing World, New York, NY: Hill and Wang.

Gable, E., Handler, R., \& Lawson, A. (1992) 'On the Uses of Relativism: Fact, Conjecture, and Black and White histories at Colonial Williamsburg', American Ethnologies, 19 (4) $791-805$.

Gieryn, T. (2000) 'A Space for Place in Sociology', Annual Review of Sociology, 26 (1) 463-96.

Goldberg, D. T. (1997) Racial subjects: Writing on race in America, New York, NY: Routledge. 
Griffin, L. (2004) 'Generations and Collective Memory' Revisited: Race, Region, and Memory of Civil Rights, American Sociological Review, 69 (4), 544-57.

Habraken, N. (1998) The Structure of the Ordinary, Cambridge, MA: MIT Press.

Hall, S. (2001) 'Museums of Modern Art and the End of History' in Campbell, S., \& Tawadros, G. (eds.), Modernity and difference (Annotation 6), London, UK: Institute of Internal Visual Arts.

Hayden, D. (1997) The Power of Place: Urban Landscaerpes and Public History, Cambridge, MA: MIT Press.

Hoelscher, S. (2003) 'Making Place, Making Race: Performances of Whiteness in the Jim Crow South', Annals of the Association of American Geographers, 93 (3), 657-86.

James, P. (2005) ‘Building a Community-based Identity at Anacostia Museum', Curator, 39 (1) $19-44$.

Karp, I., Kreamer, C., \& Lavine, S. (Eds). (1992) Museums and Communities: The Politics of Public Culture, Washington, D.C.; London, UK: Smithsonian Institution Press.

Karp, I., \& Lavine, S. (1990) Exhibiting Cultures: The Poetics and Politics of Museum Display, Washington, D.C.: Smithsonian Institution Press.

Kelly, R. (1994) Race Rebels: Culture, Politics, and the Black Working Class, New York, NY: Free Press.

Kinard, J. (1972) 'More Than Another Idea', Anacostia Neighborhood Museum. Washington, D.C.: Smithsonian Institution.

Lefebvre, H., \& Levich, C. (1987) 'The Everyday and the Everydayness', Yale French Studies, 73 (1) 1-17.

Lowe, L. (1996) Immigrant cts: On Asian American Cultural Politics, Durham, NC; London, UK: Duke University Press.

Luke, T. (2002) Museum Politics: Power Plays at the Exhibition, Minneapolis, MN; London, UK: University of Minnesota Press.

MacDonald, S. (1996) 'Theorizing Museums: An Introduction', in Macdonald, S., \& Fyfe, G. (eds), Theorizing Museums: Representing Identity and Diversity in a Changing World, 1-18, Oxford, UK; Cambridge, MA: Blackwell Publishers.

Mannheim, K. (1952) 'The Problem of Generations' in Mannheim, K., Essays on the Sociology of Knowledge, 276-321, London: Routledge \& Kegan Paul.

Margolis, C. (1972) 'Exhibits', in Anacostia Neighborhood Museum, Washington, D.C.: Smithsonian Institution.

Martin-Felton, Z., \& Lowe, G. (1993) A Different Drummer: John Kinard and the Anacostia Museum, 1967-1989, Washington, D.C.: Smithsonian Press.

Milligam, M. (2003) 'Displacement and identity discontinuity: The role of nostalgia in establishing new identity categories', Symbolic Interaction, 26 (3), 381-403.

Olick, J., \& Robbins, J. (1998) 'Social Memory Studies: From "Collective Memory" to the Historical Sociology of Mnemonic Practices', Annual Review of Sociology, 24 (1) 105-140. 
Putnam, R. (2000) Bowling Alone: The Collapse and Revival of American Community, New York, NY: Simon \& Schuster.

Ray, E. (1995) 'Black mosaic: Community, Race, and Ethnicity among Black Immigrants in Washington, D.C.', American Anthropologist, New Series, 97 (4).

Ruffins, F.D. (1998) 'Culture Wars Won and Lost, part III: The National African American Museum project', Radical History Review, 70 (1), 78-101.

Schwartz, B. (1982) 'The Social Context of Commemoration: A Study of Collective Memory', Social Forces, 61 (2), 374-402.

Spillman, L. (2002). 'Introduction: Culture and Cultural Sociology', in Spillman, L. (ed.), Cultural Sociology, 1-15, Malden, MA: Blackwell.

Swidler, A., \& Arditi, J. (1994) 'The New Sociology of Knowledge', Annual Review of Sociology, 20 (1), 305-29.

Valentine, C. (1968) Culture and Poverty: Critique and Counter Proposals, Chicago, IL: University of Chicago Press.

Zukin, S. (1995) The Culture of Cities, Cambridge, MA.; Oxford, UK: Blackwell Publishers.

${ }^{*}$ Robyn Autry is an assistant professor of sociology at Wesleyan University in CT, USA. She is a cultural sociologist with interests in race and ethnicity; memory and violence; museums; and cities. Her work on constructions of African American memory at museums was published in Theory \& Society (2013) and an article on the politics of apartheid era monuments in democratic South Africa appeared in Theory, Culture, and Society (2012). Her book Desegregating the Past: The Public Life of Memory in the US and South Africa is forthcoming with Columbia University Press,

email: rautry@wesleyan.edu 